\title{
Litter accumulation from Mucuna bracteata cover crop and its effects on some soil chemical properties in rubber plantations
}

\author{
Surani Chathurika*, Lalani Samarappuli** and Ranjith B Mapa* \\ * Department of Soil Science, Faculty of Agriculture, University of Peradeniya, Peradeniya \\ **Department of Soils and Plant Nutrition, Rubber Research Institute, Agalawatta
}

Received 26 November 2009; Accepted 25 November 2010

\begin{abstract}
Young rubber plants do not provide sufficient protection to the soil, mainly due to the poor canopy cover. Mucuna bracteata $(M B)$ has been introduced recently as a potential cover crop for young rubber plantations. This study aimed to assess the litter accumulation from $M B$ and its impact on soil properties under rubber. In this study sampling was done from different age groups of rubber (1 to 8 years) in two different rubber growing soil series, namely Boralu and Homagama series. Soil samples were collected under three different ground cover conditions, under MB $(U M)$, naturals (NA) and weed free circle (WF) at two soil depths; D1 $(0-15 \mathrm{~cm})$ and D2 $(15-30 \mathrm{~cm})$. The Experimental design was a fully nested ANOVA with three replicates. Soil organic $C$, total sol $N$, available $P$ and $K$ were measured using standard methods. Litter accumulation of $M B$ was significantly high in five years old plantation. Mean soil organic carbon was significantly different between two soil series and at different locations in a rubber plantation. Higher soil $N$ contents $(0.22-$ $0.37 \%)$ were observed in four, five and six year's old rubber plantations. Soil K content was significantly different between age of rubber plantation and at different locations in a rubber plantation. Highest soil $K$ content $(43.47 \mathrm{mg} / \mathrm{kg})$ was observed in four years old plantation and lowest value $(22.92 \mathrm{mg} / \mathrm{kg})$ was observed in the one year old plantation. Available $P$ differed significantly between different locations in a rubber plantation. Peek litter production was under four to five years old plantations and took another one to two years to achieve highest nutrient contents. Results suggest that MB improves soil fertility in 1-8 years old rubber plantations.
\end{abstract}

Key words: Mucuna bracteata, nutrients, organic carbon, rubber, soil fertility

\section{Introduction}

In Sri Lanka, rubber is grown as a rain fed plantation crop and plays an important role in its economy. Main rubber growing areas in the country are low country wet zone and mid country wet zone. These areas are sloppy lands receiving more than $2500 \mathrm{~mm}$ annual rainfall with high intensity rain storms lead to soil erosion. In addition 
continuous cultivation is also known to deplete soil nutrients and thereby lead to soil degradation (Samarappuli and Yogaratnam, 1995 \& 1996). Therefore, establishing and managing of ground cover becomes an important aspect in rubber plantations.

Cover crops may fulfill several purposes in tree crop plantations, which have long been recognized. The leguminous ground cover protect the soil from erosion, enrich it with organic matter, improves soil structure leading to better aeration, increases infiltration and retention of moisture (Samarappuli, 1992). Cover crops also minimize leaching losses of nutrients and competition from noxious weeds (Samarappuli et al, 2004), and should not compete with rubber plants for nutrients and moisture. Legumes are preferred ground covers because they fix nitrogen, which can subsequently be used by the immature rubber plants.

Traditional leguminous cover crop used in rubber plantations of Sri Lanka was Pueraria phaseoloides which does not perform successfully against weed growth (Samarappuli et al., 2004). This situation leads to inefficient management of soil and moisture under rubber. Therefore, investigation of new leguminous species with superior characteristics became essential (Samarappuli et al., 2003). Mucuna bracteata is a leguminous creeper, grown as a cover crop in rubber plantations and native to Kerala, South India. It has a very vigorous growth pattern, high drought tolerance, high biomass production, efficient control against weed growth, non palatable to livestock and tolerant to pest and diseases (Mathews, 1998, Samarappuli et al, 2004).

Due to continuous cultivation in rubber plantations organic matter can be reduced. Higher green matter and litter production of Mucuna can increase organic matter content in rubber growing soils leading to better soil fertility. Mucuna produces a thick litter layer with a thickness of three times higher than Pueraria (Samarappuli et al., 2004). The management of nutrient cycling is the function of the biomass production and the decomposition rate (Lehman et al., 2000).

Therefore, the objective of this study was to study the litter accumulation of Muuna bracteata and its contribution to the chemical properties in two selected soil series which are known as Boralu and Homagama.

\section{Materials and Methods}

This study aimed to assess the litter accumulation from Mucuna bracteata and its impact on some soil chemical properties under rubber. In this study sampling of litter and soil were done from different age groups of rubber (1 to 8 years) in two different rubber growing soil series, namely Boralu and Homagama with textural class of sandy clay loam and sandy loam, respectively (Senarath and Dassanayaka, 1999; Samarappuli, 2000).

Litter collection was done using $1 \mathrm{~m}^{2}$ frame traps and three measurements 
were taken in each field. The mean value of the three measurements was used to estimate the litter accumulation, which was extrapolated to get the per hectare value. The same sample was used for chemical analysis of N, P, K, $\mathrm{Mg}$ and $\mathrm{Ca} . \mathrm{N}$ and $\mathrm{P}$ were analyzed by colorimetric determination after using $\mathrm{Se} / \mathrm{H}_{2} \mathrm{SO}_{4}$ digestion procedure and $\mathrm{K}$ was determined by flame photometer in the SKALAR Auto Analyzer. Mg and $\mathrm{Ca}$ was determined by the single beam atomic absorption spectrophotometer model GBC 903.

Soil samples were collected from three different places or ground cover conditions, namely, under MB (UM), nearby field covered with naturals (NA) and weed free circle around the rubber plant (WF) at two soil depths; D1 (0-15 $\mathrm{cm})$ and D2 $(15-30 \mathrm{~cm})$. Soil organic C, total soil $\mathrm{N}$, available $\mathrm{P}$ and $\mathrm{K}$ were measured using standard methods. Organic C (Nelson, and Sommers, 1996), total $\mathrm{N}$ by $\mathrm{Se} / \mathrm{H}_{2} \mathrm{SO}_{4}$ digestion
(Faithfull, 2002), exchangeable $\mathrm{K}$ by Ammonium Acetate extraction (Helmke and Sparks, 1996) and available $\mathrm{P}$ by Bray II method (Bray and Kurtz, 1996) were used. Soil N content in the digested samples were determined calorimetrically using a Technicon II auto analyzer (Mulvaney, 1996), Potassium and $\mathrm{Mg}$ contents in the extraction were determine using single beam atomic absorption spectrophotometer model GBC 903 and available $\mathrm{P}$ were determined using spectrophotometer at $630 \mathrm{~nm}$ wave length.

The Experimental design was a fully nested ANOVA with three replicates.

\section{Results and Discussion}

\section{Litter accumulation of Mucuna}

Dry weight of litter accumulation at different years of rubber plantation for Homagama and Boralu soil series are shown in Table 1.

Table 1. Mean dry weight of litter accumulation with age of rubber for Boralu and Homagama soil series

\begin{tabular}{ccc}
\hline & \multicolumn{2}{c}{ Mucuna litter DW $\mathbf{~ m t} / \mathbf{h a}$} \\
\cline { 2 - 3 } Age of rubber & Boralu series & Homagama series \\
\hline 1 & $1.07^{\mathrm{b}}$ & $3.01^{\mathrm{b}}$ \\
2 & $9.82^{\mathrm{a}}$ & $8.55^{\mathrm{a}}$ \\
3 & $9.25^{\mathrm{a}}$ & $7.54^{\mathrm{a}}$ \\
4 & $9.94^{\mathrm{a}}$ & $8.48^{\mathrm{a}}$ \\
5 & $10.51^{\mathrm{a}}$ & $8.67^{\mathrm{a}}$ \\
6 & $9.95^{\mathrm{a}}$ & $8.35^{\mathrm{a}}$ \\
8 & $6.47^{\mathrm{b}}$ & $6.56^{\mathrm{b}}$ \\
\hline
\end{tabular}

Means with the same letters along the column are not significantly different 
The dry weight of Mucuna litter was not significantly different between the two soil series, but it was significantly different among different ages of rubber plantation. In both soil series, dry weight of Mucuna litter at one and eight years after replanting were significantly different from two to six years after replanting $\quad(\mathrm{p}<0.05$, using nested ANOVA). Highest litter accumulation was observed in five years old rubber plantation in Boralu series soils. Six to eight years after replanting, litter accumulation of Mucuna showed a reduction (Table 1). This may be as a result of the increase in shade with the age of the rubber as Mucuna receives low sun light due to increase of rubber tree canopy. Due to this growth reduction, litter accumulation can also be reduced. Mathews (1998) and Samarappuli (2007) also reported that under shade Mucuna cover crop could grow, but growth was comparatively less.

Chiu et al. (2001) found dry litter production by Mucuna were $19.6 \mathrm{mt} / \mathrm{ha}$ in the open and $8.7 \mathrm{mt} / \mathrm{ha}$ under shade of rubber. Samarappuli et al. (2004) reported $6.75 \mathrm{mt} / \mathrm{ha}$ of litter accumulation under Mucuna. Total dry matter production of Mucuna litter in the present study was around 9-10 mt/ha which was in agreement with those reported by Mathews (1998) and Samarappuli et al. (2004). It is important to compare litter production of Mucuna with other commonly used leguminous cover crop, Pueraria. The reported litter production values of Pueraria was 1- $2 \mathrm{mt} / \mathrm{ha}$ (Mathews, 1998) and $2 \mathrm{mt} / \mathrm{ha}$ (Samarappuli, 2004). There was much higher litter production for Mucuna than Pueraria. Therefore, Mucuna can provide thicker mulch cover and higher soil carbon and nutrient contents than Pueraria.

\section{Nutrient content of Mucuna leaf and litter}

The importance of the cover crop for the nutrient recycling of the cropping system depends on the amount of litter added and the rates of nutrient are recycling. The magnitude of the nutrient recycling is a function of biomass production, the nutrient contents and the decomposition rate (Lehmann et al., 2000).

Nutrient availability of leaf and litter of Mucuna are shown in Table 2. These are much higher than the $2.26 \%$ of $\mathrm{N}$, $0.1 \%$ of $\mathrm{P}, 0.25 \%$ of $\mathrm{K}$ and $0.15 \%$ of $\mathrm{Mg}$ reported by Chiu et al., (2001) for Mucuna under oil palm. These differences may be due to the differences in the sampling period and nutrient status of soil. Legumes generally have high foliar $\mathrm{N}$ contents typically ranging from 20 to $45 \mathrm{mg} / \mathrm{g}$. They are also rich in other nutrients like P, K and Ca (Szott, 1987). 
Table 2. Available major and secondary nutrients in leaf and litter of Mucuna cover crop

\begin{tabular}{lcc}
\hline & \multicolumn{2}{c}{$(\%)$ Dry matter } \\
\cline { 2 - 3 } Nutrients & Leaf & Litter \\
\hline $\mathrm{N}$ & 4.29 & 3.18 \\
$\mathrm{P}$ & 0.35 & 0.27 \\
$\mathrm{P}$ & 0.83 & 0.28 \\
$\mathrm{M}$ & 0.17 & 0.16 \\
$\mathrm{Ca}$ & 0.29 & 0.58 \\
\hline
\end{tabular}

\section{Chemical properties of soil}

Organic matter is an important parameter which improves soil chemical, physical and biological properties. Higher organic matter layer on soil surface would prevent the direct impact of rain drops, thus preventing the breakdown of soil structure.

A mulch layer on soil surface also act as a barrier against the kinetic energy exerted by rain drops (Samarappuli, 1995). Changes of soil organic $C$ under Mucuna and weed free circle for both soil series are shown in Figure 1. Organic C in top soil (0 $-15 \mathrm{~cm}$ depth) was significantly different between the two soil series ie, Boralu and
Homagama and between the two locations i.e., under Mucuna and weed free circle around the rubber plants ( $\mathrm{p}<0.05$, using nested ANOVA). The highest $\mathrm{C}$ was observed in Homagama series soils under Mucuna. Samarappuli (2004) observed $1.1 \%$ organic carbon content under Pueraria and it was lower than that under Mucunaa (2.8\%), which indicated higher build- up of organic $\mathrm{C}$ under Mucuna. In general, soil organic $\mathrm{C}$ differed significantly between location $\quad(\mathrm{p}<0.05$, using nested ANOVA) and also with top soil and sub soil (Table 3). Top soil showed higher organic $\mathrm{C}$ than sub soil.

Table 3. Mean soil organic $C$ in different soil depth at different locations

\begin{tabular}{|c|c|c|}
\hline \multirow[t]{2}{*}{ Location } & \multicolumn{2}{|c|}{ Organic C \% } \\
\hline & $0-15 \mathrm{~cm}$ & $15-30 \mathrm{~cm}$ \\
\hline Mисипа & 1.72 & 1.34 \\
\hline Weed Free & 1.23 & \pm 0.25 \\
\hline Naturals & 1.52 & 1.12 \\
\hline
\end{tabular}




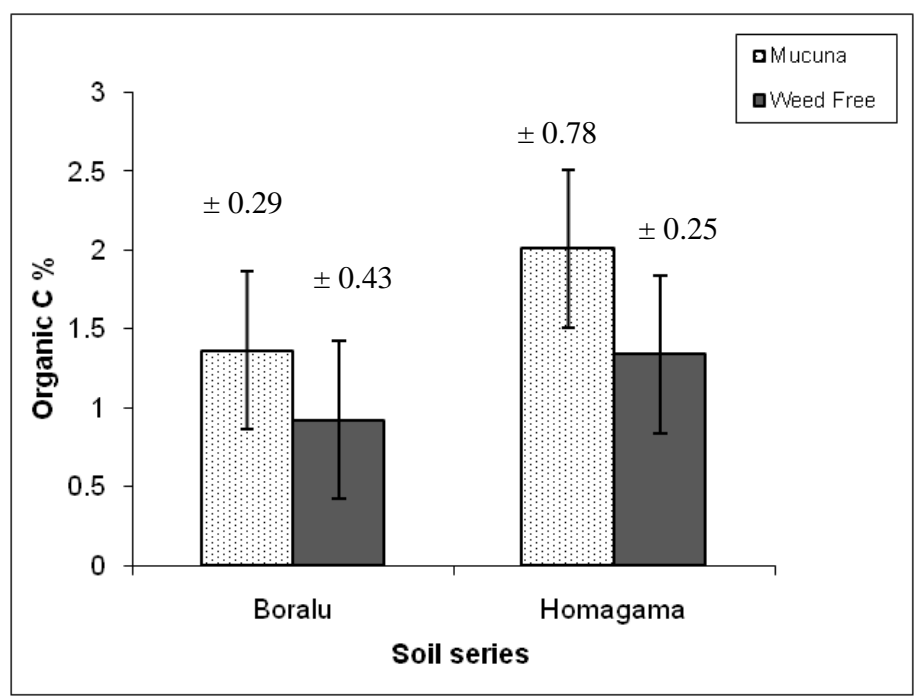

Fig. 1. Changes of mean Soil organic C in Mucuna and weed free circle in both soil series (Horizontal bars shows \pm standard deviation)

The changes in soil total $\mathrm{N}$ at different depths and in different locations in rubber plantation are shown in Table 4. Soil $\mathrm{N}$ contents under rubber in different ages are presented in Figure 2. It showed a significant difference in $\mathrm{N}$ contents with different ages and locations $\quad(\mathrm{p}<0.05, \quad$ using nested ANOVA). Higher $\mathrm{N}$ contents were observed in five and six year's old plantations and lowest value was observed in the one year old plantation. Soil total N under Mucuna has increased with the age of rubber plantation in both Boralu and Homagama series soils. Samarappuli et al., (2004) reported that soil $\mathrm{N}$ under Mucuna was $0.2 \%$ and higher than that of under Pueraria.

Table 4. Mean soil nitrogen in different soil depth at different locations

\begin{tabular}{lll}
\hline Location & \multicolumn{2}{c}{ Soil Nitrogen \% } \\
\cline { 2 - 3 } & $\mathbf{0 - 1 5} \mathbf{~ c m ~}$ & $\mathbf{1 5 - 3 0} \mathbf{~ c m}$ \\
\hline Mucuna & 0.25 & 0.29 \\
Weed Free & 0.14 & 0.11 \\
Naturals & 0.12 & 0.09 \\
\hline
\end{tabular}




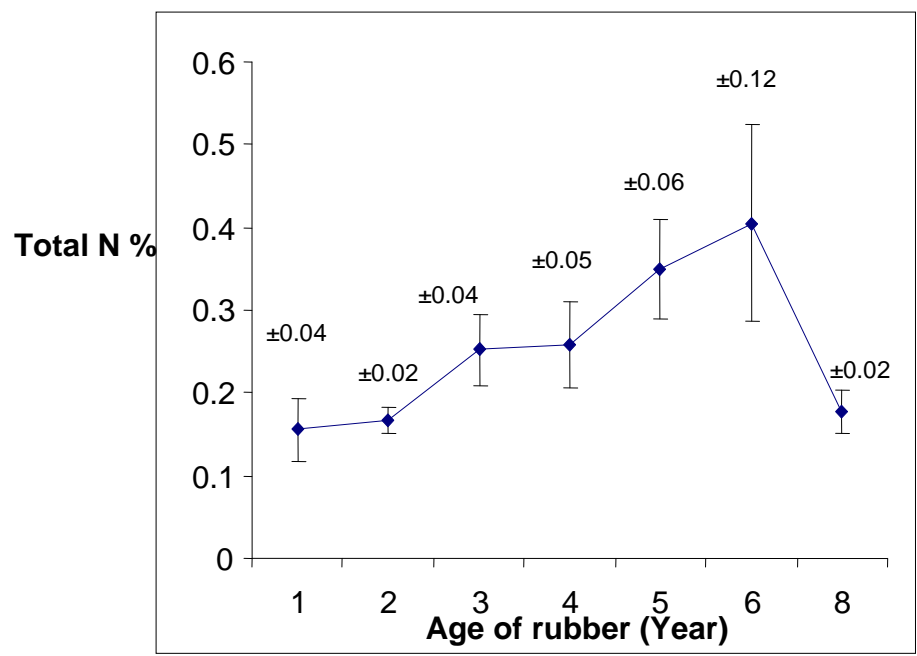

Fig. 2. Soil N under Mucuna with different age of rubber plantation

Soil $\mathrm{K}$ content was not significantly different between the two soil series but it showed a significant differences with age of the rubber plantation and location ( $\mathrm{p}<0.05$, using nested ANOVA). Soil K under Mucuna has increased with the age of rubber plantation and highest $\mathrm{K}$ content was observed in three years old plantations and lowest value was observed in the eight year old plantations (Table 5). Samarappuli et al. (2004) reported soil K under Mucuna was $64 \mathrm{ppm}$ and under Pueraria it was $43 \mathrm{ppm}$.

Soil $\mathrm{P}$ data was not significant between the soil series and age of rubber plantation but showed a significant difference with location $(\mathrm{p}<0.05$, using nested ANOVA, (Table 6). It shows that under Mucuna, higher $\mathrm{P}$ was observed than natural conditions. Samarappuli et al., (2004) reported soil P under Mucuna was 33ppm and under Pueraria it was $13 \mathrm{ppm}$.

Table 5. Changes of mean soil $K$ with different ages of rubber plantation

\begin{tabular}{lccccccc}
\hline \multirow{2}{*}{ Treatments } & \multicolumn{7}{c}{ Soil K $\mathbf{~ m g / k g}$ (Age of plantation) } \\
\cline { 2 - 8 } & $\mathbf{1}$ & $\mathbf{2}$ & $\mathbf{3}$ & $\mathbf{4}$ & $\mathbf{5}$ & $\mathbf{6}$ & $\mathbf{8}$ \\
\hline Under Mucuna & $36.17^{\mathrm{a}}$ & $27.04^{\mathrm{a}}$ & $57.30^{\mathrm{a}}$ & $33.89^{\mathrm{a}}$ & $30.00^{\mathrm{a}}$ & $19.91^{\mathrm{a}}$ & $22.34^{\mathrm{a}}$ \\
Naturals & $36.04^{\mathrm{b}}$ & $37.27^{\mathrm{a}}$ & $50.57^{\mathrm{b}}$ & $25.69^{\mathrm{b}}$ & $21.81^{\mathrm{a}}$ & $22.97^{\mathrm{b}}$ & $23.12^{\mathrm{a}}$ \\
\hline
\end{tabular}

(Means with the same letters along the column are not significantly different) 
Mucuna litter on soil chemical properties

Table 6. Mean available Soil $P$ under Mucuna and naturals

\begin{tabular}{lc}
\hline Treatments & $\begin{array}{c}\text { Available soil P } \\
\mathbf{m g} / \mathbf{k g}\end{array}$ \\
\hline Under Mucuna & $10.92^{\mathbf{a}}$ \\
Naturals & $6.81^{\mathbf{b}}$ \\
\hline
\end{tabular}

(Means with the same letters along the column are not significantly different)

Possible explanation for the better nutrient content under Mucuna could be that it has a deep root system, which allows uptake of nutrients from more deeper layers of soil. Further, weed growth was significantly less while the competition for nutrient was also less.

\section{Conclusions}

The maximum litter production of Mucuna was observed in the five years old rubber plantation $(10.51 \mathrm{mt} / \mathrm{ha})$ in Boralu series soils. Soil nutrient contents were higher under Mucuna than natural condition (without Mисипа) and weed free circle around rubber plants in a rubber plantation. Possible explanation for the better nutrient content under Mucuna could be that it has a deep root system, which allows uptake of nutrients from more deeper layers of soil. Further, weed growth was significantly less while the competition for nutrient was also less. Another advantage of Mucuna is the increase in soil cation exchange capacity due to increase in soil organic C. This probably contributed to an improved fertility condition of soils under Mucuna.
Therefore, it can be concluded that Mucuna improves soil fertility in rubber plantations, mainly due to its high contribution of litter to the soil.

\section{References}

Bray, R H and Kartz, L T (1945). Determination of total, organic and available forms of Phosphorus in soils. Soil Science 5939-45.

Chiu, S B, Aloysius, S and Emilia, F (2001). Mucuna bracteata - Supper legume cover crop revisited. The Planter $\mathbf{7 7}$, 575-583.

Faithfull, N T (2002). Methods in agricultural chemical analysis. CABI Publishing, Wallingford.

Helmke, P A and Sparks, D L (1996). Lithium, Sodium, Potassium, Rubidium and Cesium. In: Method of Soil Analysis. Part 3, Chemical Methods: D.L. Sparks (Ed). American Society of Agronomy, Soil Science Society of America, Madison, Wisconsin, USA. 568-569.

Lehmann, J, Silva, J P, Trujillo, Jr and Uguen, K (2000). Legume cover crops and nutrient cycling in tropical fruit tree production. Acta Horticulture 531, 6572.

Mathews, C (1998). Introduction and establishment of a new leguminous cover plant, Mucuna bracteata under oil palm in Malaysia. The Planter 74, 359368.

Mulvaney, R L (1996). Nitrogen - inorganic forms. In: Methods of Soil Analysis, Part 3, Chemical Methods: D L Sparks (Ed). American society of Agronomy, Soil Science Society of America, Madison, Wisconsin, USA. 1151-1152.

Nelson, D W and Sommers, L E (1996). Total carbon, organic carbon and organic matter. In: Methods of Soil Analysis. 
Part 3, Chemical Methods: D L Sparks (Ed). American Society of Agronomy, Soil Science Society of America, Madison, Wisconsin, USA. 995-996.

Samarappuli, Lalani (1992). Some agronomic aspects in overcoming moisture stress in Hevea brasiliensis. Indian Journal of Natural Rubber Research 5, 127-132.

Samarappuli, L (1995). The contribution of rubber plants towards a better environment. Bulletin of the Rubber Research Institute of Sri Lanka 33, 4554.

Samarappuli, Lalani and Yogaratnam, N (1995). Rubber plantations as a selfsustaining agro forestry system. The Sri Lanka Forester xxii, 1\&2, 13-24.

Samarappuli, Lalani and Yogaratnam, N (1996). Soil degradation and development practices in Hevea plantations. Journal of the National Institute of Plantation Management 12 (1), 48-60.

Samarappuli, Lalani (2000). Rubber growing soils and their characteristics. Bulletin of the Rubber Research Institute of Sri Lanka 41. 10-21.

Samarappuli, L, Karunadasa, P, Mithrasena, U and Shantha, N (2003). Mucuna bracteata: Ideal ground cover for efficient soil and water management in rubber cultivation. Tropical Agricultural Research and Extension 6, 85-90.

Samarappuli, L, Karunadasa, P, Mithrasena, U and Gunathilaka, T (2004). Mucuna bracteata as a cover crop for rubber in Sri Lanka. Symposium in Plant and Crop Research, 87-94.

Samarappuli, Lalani (2007). Soils and Plant Nutrition Department. Annual Review of the Rubber Research Institute of Sri Lanka, 2007, 80-81.

Senarath, A and Disanayake, A R (1999). Soils of the Low Country Wet Zone. 37 91. In: R B Mapa, S Somasiri and S Nagarajah (Ed.). Soils of the Wet Zone of Sri Lanka. Soil Science Society of Sri Lanka, Sarvodaya Vishva Lekha, Rathmalana, Sri Lanka.

Szott, L (1987). Improving the productivity of shifting cultivation in the Amazon basin of Peru through the use of leguminous vegetation. Plant and Soil 31, 324-327.

Address for correspondence: Dr Lalani Samarappuli, Head, Soils \& Plant Nutrition Dept., Rubber Research Institute of Sri Lanka, Dartonfield, Agalawatta, Sri Lanka. e-mail:lalani57@gmail.com 